\title{
PENINGKATAN MUTU GENETIK INDUK DAN CALON INDUK KAMBING PE PROLIFIK MELALUI PEMANFAATAN PAKAN KULIT BUAH KAKAO
}

\author{
Zulkharnaim, Jasmal A Syamsu, Muhammad Ihsan A Dagong, Sahiruddin Sabile
}

\author{
Fakultas Peternakan Universitas Hasanuddin \\ Jl. Perintis Kemerdekaan KM 10, Makassar, Sulawesi Selatan \\ e-Mail : zulmaupa@gmail.com
}

\begin{abstract}
ABSTRAK
Pod husks from waste cocoa crops used as alternative feed goats Peranakan Etawah. This study aims to determine the impact of the pod husks as a feed supplement to increase body size of adult female and parent in preparing for pregnancy. A total of 30 goats were divided into 16 tails dara and 14 breeding, reared intensively for 60 days. Pod husks were feeding as many as 1000-1500 g / head / day. The analysis used the PCR RFLP. The results showed the average growth of Body Lenght for the adult female, the prolific parent and single parent respectively by $1.75,2: 18$ and $1: 59 \mathrm{~cm}$, while the average increase respectively Shoulder Height 1:49, and 1:12 $1.97 \mathrm{~cm}$. The results of the analysis of PCR RFLP GH MspI produced three genotypes, namely TT; TC and CC. Obtained genotype frequencies of TT (0091); TC (0409) and CC (0500). GH MspI gene polymorphism is not associated with the prolific nature, but related with the average increase in body size. It can be seen in the TT genotype showed the average increase Body Lenght $(2.26 \mathrm{~cm})$ and Shoulder Height (1.80), while TC and CC is almost the same (not different). Program selection on the growth potential of goats can use TT genotype.
\end{abstract}

Key word : PE Goats, body size, prolific, GH MspI gene

Kulit buah kakao yang berasal dari limbah hasil panen kakao dimanfaatkan sebagai pakan tambahan kambing PE. Penelitian ini bertujuan mengetahui dampak pemberian KBK sebagai pakan tambahan untuk meningkatkan kondisi induk dan calon induk dalam mempersiapkan kebuntingan. Sebanyak 30 ekor kambing PE yang terbagi dalam 16 ekor dara dan 14 ekor induk, dipelihara secara intensif selama 60 hari. Pemberian pakan KBK sebanyak 1000-1500 g/ekor/hari. Analisa yang digunakan yakni PCR RFLP. Hasil penelitian menunjukkan rataan pertumbuhan $P B$ untuk dara, induk prolifik dan induk tunggal masing-masing sebesar 1.75, 2.18 dan $1.59 \mathrm{~cm}$, sedangkan rataan pertambahan TP masing-masing 1.49, 1.97 dan $1.12 \mathrm{~cm}$. Hasil analisis PCR RFLP GH MspI menghasilkan tiga genotipe, yakni TT; TC dan CC. Frekuensi genotipe didapatkan sebesar TT (0.091); TC (0.409) dan CC (0.500). Polimorfisme gen GH MspI tidak berhubungan dengan sifat prolifik, namun berhubungan dengan rataan pertambahan ukuran tubuh. Hal tersebut dapat dilihat pada genotipe TT menunjukkan rataan pertambahan $P B(2,26 \mathrm{~cm})$ dan TP $(1,80)$, sedangkan TC dan CC hampir sama (tidak berbeda). Program seleksi terhadap potensi pertumbuhan kambing PE dapat menggunakan genotipe TT.

Kata Kunci : Kambing PE, Ukuran Tubuh, Prolifik, Gen GH 


\section{PENDAHULUAN}

Salah satu jenis kambing yang banyak diternakkan di Indonesia adalah kambing Peranakan Etawah (PE). Kambing PE merupakan hasil perkawinan silang antara kambing Etawah dengan kambing Kacang (lokal) Indonesia. Kambing Peranakan Etawah atau yang lebih dikenal sebagai kambing PE, telah menjadi salah satu plasma nutfah Indonesia. Kabupaten Polewali Mandar merupakan salah satu daerah yang menjadi pusat pengembangan kambing PE di Provinsi Sulawesi Barat, dimana sebagian besar peternak/kelompok telah menerapkan seleksi terhadap sifat prolifik dan pertumbuhan.

Pemanfaatan limbah perkebunan sebagai pakan menjadi alternatif dalam pengembangan peternakan Kambing PE rakyat. Salah satu limbah perkebunan yang banyak ditemui di Kabupaten Polewali Mandar, Provinsi Sulawesi Barat adalah kulit buah kakao (KBK). Tanaman kakao memiliki potensi sebagai penyedia hijauan pakan ternak ruminansia yakni daun kakao (limbah pangkasan) dan kulit buah kakao (pod cocoa husk) setelah bijinya dikeluarkan. Kulit buah kakao memiliki kandungan bahan kering $(18,7 \%)$, protein $(9,9 \%)$, serat kasar (32,7\%) dan lemak (9,2\%) (Munier, 2007). Dengan potensi kandungan yang dimilikinya, membuat KBK yang dulunya hanya dianggap sebagai limbah perkebunan kakao menjadi pakan tambahan pada ternak kambing.

Permasalahan dalam pengembangan peternakan terutama di daerah perkebunan, yakni semakin terbatasnya ketersediaan pakan hijauan yang disebabkan semakin menyempitnya padang penggembalaan. Penyempitan padang penggembalaan disebabkan adanya perluasan areal persawahan dan perkebunan rakyat. Dengan penemuan pemanfaatan limbah KBK menjadi salah satu sumber pakan, menjadikan peternak dapat mengembangkan pola peternakan sistem integrasi peternakan-perkebunan. Pengembangan areal tanaman kakao memiliki berpotensi dalam menyediakan hijauan pakan untuk ternak ruminansia baik berupa limbah tanaman kakao maupun daun gamal (Gliricidia sepium) sebagai tanaman penaung tanaman kakao.

Kualitas dan jenis pakan sangat mempengaruhi pertumbuhan dan perkembangan Kambing PE. Setiap fase pertumbuhan dan perkembangan ternak kambing membutuhkan asupan pakan yang berbeda, terutama pada fase persiapan perkawinan dan kebuntingan kambing betina. Pada fase persiapan perkawinan dan kebuntingan induk dan calon induk kambing PE membutuhan asupan protein, karbohidrat dan lemak yang lebih dibandingkan fase lainnya. Menurut Ramadhan et al. (2013) kebutuhan BK, PK, dan TDN induk kambing Peranakan Etawah berdasarkan bobot badan metabolis adalah 106,66 g/kgBB/hari; 17,27 g/kgBB/hari; dan 65,55 g/kgBB/hari. Ditambahkan oleh Marwah et al. (2010) kebutuhan BK, PK, dan TDN kambing Peranakan Ettawa yang sedang laktasi adalah 1,867 kg/hari, 0,344 kg/hari, dan 1,105 kg/hari. Pemberian KBK pada kambing betina yang sedang bunting sebagai pakan tambahan dapat membantu untuk memenuhi kebutuhan hidup pokok dan perkembangan calon anak (foetus) yang sedang dikandungannya (Munier, 2007).

Tinggi rendahnya bobot lahir (birth weight) anak kambing sangat dipengaruhi oleh kondisi induknya saat masa kebuntingan. Faktor utama yang paling menentukan adalah pakan yang berkaitan dengan jumlah dan mutu pakan yang dikonsumsi kambing. Kebutuhan pakan bagi kambing yang sedang bunting melebihi porsi pada kambing yang tidak bunting karena kebutuhan untuk hidup pokok calon induk dan untuk pertumbuhan calon anak yang dikandungnya. Kekurangan pakan (unsur nutrisi) umumnya mengakibatkan lemahnya fisik calon induk, produksi air susu rendah menjelang 
kelahiran, kondisi fisik anak lemah dan bobot lahir rendah. Namun apabila kebutuhan pakan kambing bunting dapat dipenuhi bahkan berlebih maka akan meningkatkan kondisi fisik calon induk, produksi air susu cukup menjelang kelahiran, kondisi fisik anak sehat dan diikuti dengan bobot lahir yang tinggi. Hasil penelitian (Munier, 2008) menunjukkan perbedaan bobot lahir anak yang tinggi pada induk yang diberikan pakan tambahan KBK dengan perbandingan, bobot lahir tanpa pemberian KBK $2,55 \mathrm{~kg}$, sedangkan dengan pemberian KBK sebesar 3,03 kg.

Kulit buah kakao (KBK) yang merupakan limbah perkebunan dapat dimanfaatkan sebagai pakan alternatif. Ketersediaan KBK cukup tinggi, disebabkan limbah dari proses pemanenan buah kakao yang tertinggi adalah KBK yaitu 73,73-74,00\% (Munier. 2007). Pemberian KBK pada kambing PE bunting meningkatkan rataan bobot hidup (Prabowo dan Bahri. 2002). Pemberian KBK pada ternak kambing tidak melebihi dari kisaran 30 $70 \%$ dari total pakan (Mahyuddin dan Bakrie, 1993), hal ini disebabkan KBK mengandung senyawa pembatas yakni Theobromine atau 3,7-Dimethylxanthine, senyawa ini dapat mempengaruhi kesehatan ternak ruminansia.

Arah pengembangan kambing PE yakni pada pemanfaatan potensi sifat prolifik dan pertumbuhan yang cepat. Terkait potensi genetik, sifat prolifik dan pertumbuhan sangat ditentukan oleh dua hal, yakni; seleksi yang ketat terhadap sifat tersebut dan genetik bawaan oleh jenis ternak tertentu. Selain faktor genetik, sifat prolifik dan pertumbuhan juga dipengaruhi oleh faktor pakan, manajemen dan faktor lingkungan. Kisaran umur estrus pertama bagi kambing PE adalah $9-10$ bulan, dengan rataan umur pertama kawin pada daerah pantai 12,5 bulan dan daerah gunung 13,2 bulan (Utomo, 2013).

Parameter dalam penentuan calon induk yang berpotensi memiliki sifat prolifik adalah ukuran tubuh yang meliputi panjang badan dan tinggi badan. Induk kambing yang mempunyai kemampuan sifat prolifik menunjukkan bahwa kambing tersebut kambing yang besar, tumbuh lebih cepat dan lebih besar ukurannya pada saat mencapai kedewasaan, sehingga ia memiliki ukuran panjang badan dan tinggi pundak yang lebih besar dibandingkan dengan induk yang beranak tunggal. Pertumbuhan ukuran tubuh dipengaruhi oleh potensi genetik yang dimiliki oleh calon induk.

Salah satu faktor yang mempunyai peranan di dalam pertumbuhan suatu individu adalah growth hormone (GH). GH diperlukan untuk pertumbuhan jaringan, metabolisme lemak, dan pertumbuhan tubuh normal (Sumantran, et al, 1992). Disebabkan fungsinya yang penting, GH merupakan kandidat gen untuk program Marker Asissted Selection pada kambing PE. Pituitari hormon utama yang menyebabkan pertumbuhan adalah Growth Hormone. GH telah terbukti menjadi pengatur utama pada pertumbuhan pasca kelahiran, metabolisme pada mamalia, kecepatan pertumbuhan, susunan tubuh dan kesehatan (Mitra, et al, 1995).

Pemberian KBK sebagai pakan sebagai upaya pemanfaatan limbah kakao yang ketersediaannya berlimpah dan ditujukan untuk mempercepat kondisi induk dan calon induk dalam mempersiapkan kebuntingan. Pentingnya GH pada pertumbuhan kambing PE terutama pada persiapan kebuntingan induk dan calon induk membutuhkan kajian yang lebih mendalam mengenai keterkaitan antara pertumbuhan dan polimorfisme gen GH. Polimorfisme tersebut menjadi informasi penting dalam meningkatkan mutu genetik ternak, dan hubungan dengan peningkatan potensi/ kesiapan kelahiran prolifik. 


\section{MATERI DAN METODE}

Kegiatan pengkajian ini dilaksanakan di Desa Renggeang, Kecamatan Tinambung, Kabupaten Polewali Mandar, Provinsi Sulawesi Barat. Sebagai materi penelitian yaitu 30 ekor kambing PE yang terbagi dalam 16 ekor dara dan 14 ekor induk, dipelihara secara intensif selama 60 hari. Pemberian pakan KBK sebanyak 1000-1500 $\mathrm{g}$ /ekor/hari dan diberikan pada siang hari. Pengukuran panjang badan (PB) dan Tinggi Pundak (TP) dilakukan pada awal dan akhir penelitian.

Koleksi darah sebagai materi informasi genetik (DNA) dilaksanakan pada akhir perlakuan, untuk melihat dampak pemberian pakan KBK. Koleksi darah menggunakan tabung dengan anti koagulan EDTA. Untuk parameter fisiologis darah, penanganan sampel darah dilakukan dengan pemisahan plasma yang dilakukan 30 menit setelah pengambilan, pemisahan menggunakan centrifuge kecepatan 3000 rpm selama 15 menit. Plasma darah disimpan dalam freezer suhu $-30^{\circ} \mathrm{C}$ sampai dilakukan pemeriksaan laboratorium.

Parameter fisiologis plasma darah antara lain glukosa, ALT, AST dan kolesterol plasma darah diukur menggunakan Cobas $\mathrm{C} 111$ menggunakan reagent standar (Roche Diagnostic GmbH, Jerman). Pelaksanaan analisis di Laboratorium Fisiologi Ternak Universitas Hasanuddin. Analisis polimorfisme gen GH dilaksanakan di Laboratorium Terpadu Fakultas Peternakan Universitas Hasanuddin. Pelaksanaan ekstraksi DNA dikerjakan dengan menggunakan kit ekstraksi DNA (Gsync ${ }^{T M}$ DNA Extraction Kit, produk Geneaid).

Amplifikasi DNA menggunakan primer maju 5'CCCACGGGCAAGAATGAGGC-3' dan primer balik 5'-GAGGAACTGCAGGG GCCCA-3' (Mitra, et al, 1995). Dengan panjang fragmen 327 pb. Untuk mengidentifikasi genotipe yang terbentuk, maka digunakan enzim retriksi MspI (C|CGG). Reaksi PCRRFLP (Polymerase Chain Reaction-Fragment Length Polymorphism) sebanyak $25 \mu \mathrm{L}$ terdiri dari $2 \mu \mathrm{L}$ sampel DNA, primer maju dan balik masing-masing $0,3 \mu \mathrm{L}, 2,5 \mu \mathrm{L}$ 10xPCR buffer, $1 \mu \mathrm{L} \mathrm{MgCl}, 0,3 \mu \mathrm{L}$ dNTPs, $0.1 \mathrm{U} / \mu \mathrm{L}$ Taq DNA polymerase, dan dH2O. Kondisi PCR meliputi denaturasi awal pada suhu $95^{\circ} \mathrm{C}$ selama 4 menit, kemudian dilanjutkan 35 siklus yaitu denaturasi pada suhu $95^{\circ} \mathrm{C}$ selama 45 detik, suhu penempelan primer $62^{\circ} \mathrm{C}$ selama 30 detik dan suhu pemanjangan pada $72^{\circ} \mathrm{C}$ selama 1 menit, setelah itu suhu akhir pemanjangan pada $72^{\circ} \mathrm{C}$ selama 10 menit.

Frekuensi alel gen GH diperoleh dari analisis penciri PCR-RFLP MspI dihitung menggunakan rumus (Nei, 1987) :

Keterangan :

$$
x_{i}=\frac{\left(2 n_{i i}+\sum_{j \neq i} n_{i j}\right)}{2 n}
$$

$\mathrm{x}_{\mathrm{i}}=$ frekuensi alel ke-i

$\mathrm{n}_{\mathrm{ii}}=$ jumlah individu bergenotipe $\mathrm{A}_{\mathrm{i}} \mathrm{A}_{\mathrm{i}}$

$n_{i j}=$ jumlah individu bergenotipe $A_{i} A_{j}$

$\mathrm{n}=$ jumlah total sampel.

Keragaman genetik (genetic variability) dilakukan melalui estimasi frekuensi heterozigositas pengamatan $\left(\mathrm{H}_{\mathrm{o}}\right)$, heterozigositas harapan $\left(\mathrm{H}_{\mathrm{e}}\right)$ dan standar eror heterozigositas harapan (Nei, 1987): 
Keterangan :

$$
H_{o}=\sum_{i \neq j} \frac{N_{1 i j}}{N}
$$

$\mathrm{H}_{\mathrm{o}}=$ frekuensi heterozigositas pengamatan

$\mathrm{N}_{1 \mathrm{ij}}=$ jumlah individu heterozigositas pada lokus ke-1

$\mathrm{N}$ = jumlah individu yang dianalisis

$$
H_{e}=1-\sum_{1=1}^{n} p_{1 i}^{2}
$$

Keterangan :

$\mathrm{H}_{\mathrm{o}}=$ heterozigositas harapan

$\mathrm{P}_{1 \mathrm{i}}=$ frekuensi alel ke-I pada lokus 1

$\mathrm{n}$ = jumlah alel pada lokus ke-1

\section{HASIL DAN BAHASAN}

Sistem pemeliharaan kambing di lokasi pengkajian dilaksanakan secara intensif, jenis pakan yang diberikan berupa leguminosa lamtoro. Pemberian KBK sebagai pakan tambahan memberikan hasil yang cukup baik, ditunjukkan dengan pertambahan ukuran panjang badan dan tinggi pundak yang cukup besar (Tabel 1).

Tabel 1. Rataan Pertambahan Ukuran Tubuh Kambing PE Pasca Pemberian KBK

\begin{tabular}{|l|c|c|c|}
\hline \multirow{2}{*}{ Parameter } & \multicolumn{3}{|c|}{ Status Ternak (cm) } \\
\cline { 2 - 4 } & Dara & $\begin{array}{c}\text { Induk } \\
\text { (Prolifik) }\end{array}$ & $\begin{array}{c}\text { Induk } \\
\text { (Tunggal) }\end{array}$ \\
\hline $\begin{array}{l}\text { Panjang } \\
\text { Badan (PB) }\end{array}$ & 1.75 & 2.18 & 1.59 \\
\hline $\begin{array}{l}\text { Tinggi } \\
\text { Pundak (TP) }\end{array}$ & 1.49 & 1.97 & 1.12 \\
\hline
\end{tabular}

Pemberian KBK pada kambing PE induk tunggal menunjukkan pertambahan panjang badan terendah sebesar $1.59 \mathrm{~cm}$, sedangkan pertambahan tertinggi pada induk yang prolifik sebesar $2.18 \mathrm{~cm}$. Kondisi umur menjadi penyebab perbedaan antara dara dan induk. Namun pada kondisi umur yang relatif hampir sama yakni $1.5-2$ tahun, perbedaan antara induk prolifik cukup besar dibandingkan induk tunggal (1 anak/kelahiran).

Rataan ukuran PB pada dara diakhir pemberian pakan KBK sebesar 70.03 \pm 5.76 $\mathrm{cm}$, induk prolifik sebesar $74.83 \pm 2.50 \mathrm{~cm}$, sedangkan induk tunggal $74.25 \pm 3.98 \mathrm{~cm}$. Rataan PB hasil penelitian berbeda dengan hasil pengukuran kambing PE di Desa Banyuringin, Kecamatan Singorojo, Kabupaten Kendal, dimana PB induk prolifik sebesar $67.75 \pm 5.11 \mathrm{~cm}$ dan untuk induk tunggal sebesar $65.07 \pm 4.40 \mathrm{~cm}$, dimana 
pemeliharaan tanpa pemberian KBK (Munier, 2008). Perbedaan rataan PB tersebut menunjukkan dampak pemberian pakan tambahan KBK dapat meningkatkan ukuran PB kambing induk, maupun calon induk (dara).

Rataan pertambahan ukuran TP menunjukkan kambing PE dara sebesar $1.49 \mathrm{~cm}$, sedangkan perbedaan induk prolifik dan tunggal masing-masing sebesar 1.97 dan 1.12 $\mathrm{cm}$. Induk prolifik memiliki rataan pertambahan TP yang lebih besar jika dibandingkan dengan induk tunggal, yang mengindikasikan bahwa dalam menghasilkan jumlah kelahiran anak lebih dari 1 ekor/kelahiran membutuhkan TP dan PB yang cukup besar. Jika ditinjau pada rataan TP pada dara sebesar $71.34 \pm 3.51 \mathrm{~cm}$, induk prolifik sebesar $75.29 \pm 3.93 \mathrm{~cm}$ dan induk tunggal sebesar $74.41 \pm 3.65 \mathrm{~cm}$. Meskipun rataan TP tidak berbeda jauh, namun rataan pertambahan ukuran TP menunjukkan perbedaan.

Rataan pertambahan ukuran tubuh dara lebih tinggi dibandingkan dengan induk tunggal, hal tersebut merupakan dari hasil program seleksi yang dilaksanakan oleh peternak. Kambing PE dara yang menjadi materi penelitian merupakan hasil dari kelahiran prolifik, sehingga dapat dikatakan bahwa tingginya rataan ukuran tubuh dara menjadi potensi dalam menghasilkan induk yang prolifik. Ukuran tubuh yang cukup besar akan menjadi salah satu prasyarat penting dalam menentukan kriteria seleksi calon induk prolifik, yakni kisaran ukuran PB sebesar $70.03 \pm 5.76 \mathrm{~cm}$ dan TP sebesar $71.34 \pm 3.51 \mathrm{~cm}$.

Jumlah pemberian KBK sebanyak 1000 - 1500 g/ekor/hari masih dalam ambang batas yang aman karena pemberian KBK secara berlebihan dapat mengakibatkan gangguan kesehatan (Munier, 2008). KBK mengandung senyawa pembatas yakni theobromine atau 3.7-dimethylxanthine (Mahyuddin dan Bakrie, 1993). Pemanfaatan limbah kakao berupa KBK sebagai upaya dalam meningkatkan nilai integrasi kakaokambing PE harus sesuai dengan batasan konsumsi ternak. Pengukuran fisiologis darah pasca pemberian KBK tidak menunjukkan dampak negatif (Tabel 2).

Tabel 2. Parameter Fisiologis Pasca Pemberian KBK
\begin{tabular}{|l|c|c|c|}
\hline \multicolumn{1}{|c|}{$\begin{array}{c}\text { Parameter } \\
\text { Fisiologis }\end{array}$} & Dara & $\begin{array}{c}\text { Induk } \\
\text { (Prolifik) }\end{array}$ & $\begin{array}{c}\text { Induk } \\
\text { (Tunggal) }\end{array}$ \\
\cline { 2 - 4 } $\begin{array}{l}\text { Glukosa } \\
(\mathrm{mg} / \mathrm{dl})\end{array}$ & 48.27 & 43.46 & 34.41 \\
\hline AST (U/I) & 55.95 & 64.65 & 63.13 \\
\hline ALT (U/I) & 16.21 & 13.33 & 12.67 \\
\hline $\begin{array}{l}\text { Kolesterol } \\
(\mathrm{mg} / \mathrm{dl})\end{array}$ & 58.94 & 65.33 & 66.66 \\
\hline
\end{tabular}

Hasil pemeriksaan fisiologis plasma darah untuk mengetahui dampak pemberian KBK pada kambing, menunjukkan rataan kadar glukosa, AST, ALT dan kolesterol yang normal (Tabel 2). Rataan kadar glukosa darah pada domba secara normal pada masa tidak bunting sebesar $46.19 \mathrm{mg} / \mathrm{dl}$, AST sebesar 92.77 U/I, ALT sebesar $15.23 \mathrm{U} / \mathrm{I}$, dan kolesterol sebesar $69.04 \mathrm{mg} / \mathrm{dl}$ (Yokus, et al. 2006). Parameter fisiologis pada hasil penelitian tidak berbeda jauh dengan kondisi normal, yang mengindikasikan bahwa pemberian pakan tambahan KBK tidak akan mengganggu kesehatan ternak sepanjang tidak melampaui batasan toleransi konsumsi KBK. Pemberian pakan tambahan KBK diatas $40 \%$ dari total pakan pada kambing yang sedang bunting dikhawatirkan akan 
mengganggu kesehatan calon induk dan anak dalam kandungnya dari pengaruh theobromine dalam KBK (Mahyuddin dan Bakrie, 1993).

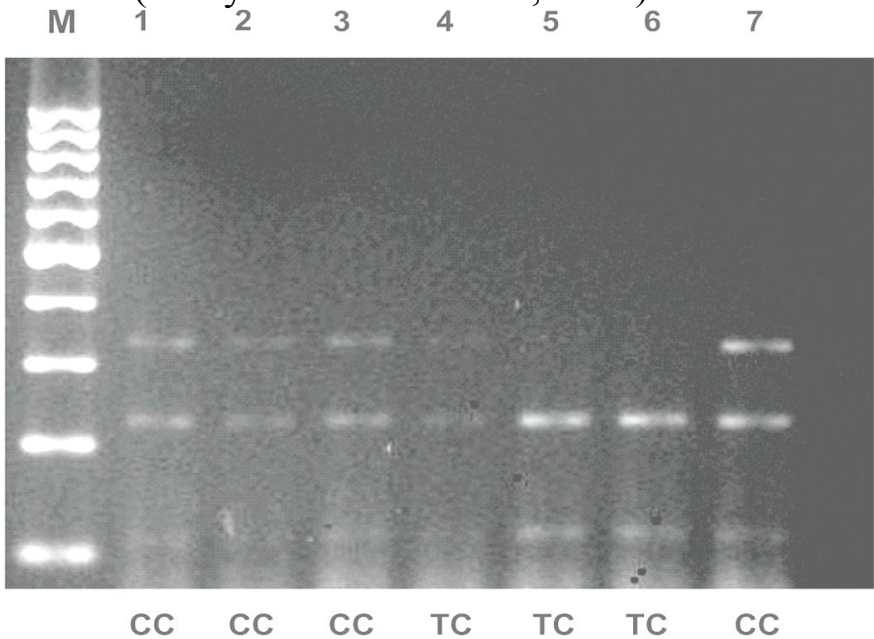

Gambar 1. Genotipe Hasil PCR RFLP GH MspI $\quad$ M (marker) = ladder $100 \mathrm{pb}$; $\mathrm{CC}=$ individu homozigot $(223,124 \mathrm{pb}) ; \mathrm{TC}=$ individu heterozigot $(327,223,124 \mathrm{pb})$

Hasil pemotongan enzim retriksi $M s p I$ pada exon 3 menghasilkan genotipe TT (327 pb), CC (223, $124 \mathrm{pb})$ dan TC (327, 223, $124 \mathrm{pb})$. Produk PCR RFLP Gh MspI dapat dilihat pada Gambar 1. Hasil analisis PCR RFLP terhadap GH MspI menunjukkan bahwa gen GH pada exon 3 memiliki genotipe yang polimorfik (Tabel 3). Terdapat 3 (tiga) genotipe, yakni TT, TC dan CC, dengan frekuensi genotipe masing-masing sebesar 0.091, 0.409 dan 0.500. Dominasi terjadi pada genotipe homozigot (CC), yang dapat dilihat pada frekuensi alel $\mathrm{C}$ sebesar 0.705 .

Nilai heterozigositas observed dan expected tidak menunjukkan perbedaan yang signifikan, sehingga mengindikasikan populasi secara genetic masih dalam keadaan seimbang. Perbedaan antara nilai $\mathrm{Ho}$ dan $\mathrm{He}$ mengindikasikan bahwa telah terjadinya ketidakseimbangan $\mathrm{H}-\mathrm{W}$, yaitu perubahan frekuensi gen yang cukup besar dari satu generasi ke generasi lainnya disebabkan oleh adanya seleksi, migrasi, mutasi dan genetic drift (Noor, 2008).

Tabel 3. Hasil Analisis PCR RFLP GH M
\begin{tabular}{c|c|}
\hline Parameter & $\begin{array}{c}\text { Analisis PCR } \\
\text { RFLP }\end{array}$ \\
\hline Frekuensi Genotipe \\
\hline TT & 0.091 \\
\hline TC & 0.409 \\
\hline CC & 0.500 \\
\hline Frekuensi Alel \\
\hline \multicolumn{2}{|c|}{ T } \\
\hline C & 0.295 \\
\hline Heterosigositas \\
\hline Hobserved $^{\text {Hexpected }}$ & 0.705 \\
\hline
\end{tabular}


Tabel 4. Rataan Pertambahan Ukuran Tubuh Berdasarkan Genotipe

\begin{tabular}{|l|c|c|c|}
\hline \multirow{2}{*}{ Parameter } & \multicolumn{3}{|c|}{ Genotipe } \\
\cline { 2 - 4 } & TT & TC & CC \\
\hline Panjang Badan (PB) cm & 2.26 & 1.77 & 1.76 \\
\hline Tinggi Badan (TP) cm & 1.80 & 1.64 & 1.48 \\
\hline
\end{tabular}

Hasil rataan pertambahan ukuran tubuh berdasarkan genotipe menunjukkan individu dengan genotipe TT mempunyai rataan PB dan TP yang lebih tinggi jika dibandingkan dengan genotipe TC dan CC (Tabel 4). Individu dengan genotipe TT merupakan individu induk kambing PE, atau kambing PE dara tidak memiliki genotipe TT. Tidak ada hubungan antara genotipe dengan jumlah kelahiran anak, sehingga dapat dikatakan bahwa gen GH ekson 3 dengan lokus MspI tidak berhubungan dengan jumlah kelahiran. Hal ini disebabkan GH tidak secara langsung mempengaruhi sifat prolifik. Polimorfisme gen GH MspI dalam hal ini lebih mempengaruhi pertambahan ukuran tubuh ternak. Sehingga seleksi dengan menggunakan parameter genotipe gen GH MspI dapat dilaksanakan pada seleksi ukuran tubuh (PB dan TP).

\section{SIMPULAN}

1. Pemberian KBK sebagai pakan tambahan pada kambing PE dapat meningkatkan rataan pertambahan ukuran tubuh (PB dan TP).

2. Hasil amplifikasi gen GH lokus MspI pada ekson 3 menghasilkan polimorfisme, dengan frekuensi genotipe TT (0.091); TC (0.409) dan CC (0.500).

3. Genotipe gen GH lokus $M s p I$ tidak berhubungan secara langsung dengan sifat prolifik kambing PE, namun genotipe TT berhubungan dengan tingginya rataan pertambahan ukuran tubuh (PB dan TP).

\section{DAFTAR PUSTAKA}

Mahyuddin, P and Bakrie, B. 1993. Different Levels of Cocoa Shell in Diets of Growing Cattle, Ilmu dan Peternakan, 6 (2): 1 - 4.

Marwah, M.P., Y.Y. Suranindyah, dan T.W. Murti. 2010. Produksi dan komposisi susu kambing peranakan ettawa yang diberi suplemen daun katu (sauropus androginus(L) merr) pada awal masa laktasi. Buletin Peternakan, 34 (2) : 94-102.

Munier, FF. 2007. Bobot Hidup Kambing Peranakan Etawah (PE) Betina yang Diberikan Kulit Buah Kakao (Theobroma cocoa L), Pros. Seminar Nasional Teknologi Peternakan dan Veteriner, Bogor, 21 Agustus 2007, hlm. 410-416.

Munier, F. F. 2008. Bobot Lahir Kambing Peranakan Etawah (PE) yang Diberikan Kulit Buah Kakao (Theobroma cocoa L.) (The Birth Weight of Etawah Grade Fed on Cocoa Pod Husk (Theobroma cocoa L.). Seminar Nasional Teknologi Peternakan Dan Veteriner, 422-429.

Mitra, A., Schlee, P., Balakrishnan, CR., and Pirchner, F. 1995. Polymorphisms at Growth-Hormone and Prolactin Loci in Indian Cattle and Buffalo, Journal of 
Animal Breeding and Genetics Zeitschrift fur Tierzuchtung und Zuchtungsbiologie, 112: 71-74.

Nei, M.1987. Molecular Evolutionary Genetics, Columbia University Press, New York.

Noor, RR.2008. Genetika Ternak. Penebar Swadaya, Jakarta.

Prabowo, A dan Bahri S. 2002. Kajian Sistem Usahatani Ternak Kambing pada Perkebunan Kakao Rakyat di Lampung, Laporan Hasil Pengkajian TA. 2002, BPTP Lampung, Bandar Lampung.

Ramadhan, B. G, Suprayogi, T. H, dan Sustiyah A. 2013. Tampilan Produksi Susu dan Kadar Lemak Susu Kambing Peranakan Ettawa Akibat Pemberian Pakan dengan Imbangan Hijauan dan Konsentrat yang Berbeda. Animal Agriculture Journal, 2 (1); 354.

Sumantran, VN., Tsai, ML., Schwartz, J. 1992. Growth Hormone Induces c-fos and c-jun Expression in Cells with Varying Requirements for Differentiation. Endocrinol, 130: 2016-2024.

Utomo. S. 2013. Pengaruh Perbedaan Ketinggian Tempat Terhadap Capaian Hasil Inseminasi Buatan Pada Kambing Peranakan Ettawa. Sains Peternakan, 11 (1): $34-42$.

Yokus B., Cakir DU., Kanay Z., Gulten T and Uysal E. 2006. Effects of Seasonal and Physiological Variations on the Serum Chemistry, Vitamins and Thyroid Hormone Concentrations in Sheep. J. Vet. Med. A, 53: 271-276. 